\title{
Identification of Profitable Rice Based Cropping System for South Konkan Coastal Zone
}

\author{
A.P. Chavan ${ }^{1}$, N.G. Sonone ${ }^{1 *}$, M.S. Jadhav ${ }^{1}$ and V.V. Sagvekar ${ }^{2}$ \\ ${ }^{1}$ Agricultural Research Station, Phondaghat, Ta. Kankavli, Dist. Sindhudurg \\ (MS) - 416 601, India \\ ${ }^{2}$ Agriculture Technical School, Lanja, Dist. Ratnagiri (MS) - 416 712, India \\ *Corresponding author
}

\begin{tabular}{|c|}
\hline Keywords \\
\hline $\begin{array}{l}\text { Rice based cropping } \\
\text { system, Land use } \\
\text { efficiency, Field water } \\
\text { use efficiency, Net return } \\
\text { etc. }\end{array}$ \\
\hline Article Info \\
\hline $\begin{array}{l}\text { Accepted: } \\
\text { 04 September } 2018 \\
\text { Available Online: } \\
10 \text { October } 2018\end{array}$ \\
\hline
\end{tabular}

\section{A B S T R A C T}

Field experiments were conducted for three consecutive kharif-rabi seasons of 2012-13, 2013-14 and 2014-15 at Agricultural Research Station, Phondaghat, Dist. Sindhudurg (MS) India. The experiments were conducted with ten rice based cropping systems with an objective to find out most profitable rice based cropping system suitable for South Konkan Coastal Zone. The crops in sequences after kharif rice included one oilseed crop i.e. groundnut, two pulse crops viz. cowpea and wal, one cereal crop i.e. sweet corn; five vegetable crops viz. brinjal, chilli, cabbage, okra, watermelon besides rice followed by fallow during rabi season. Three years pooled data indicated that among different rice based crops cultivated during rabi after kharif rice, brinjal recorded higher fruit yield followed by watermelon, cabbage and sweet corn. Whereas, rice equivalent yield of rabi crops as well as rice equivalent yield of system were higher with brinjal followed by sweet corn, okra and chilli. The system productivity in terms of rice equivalent grain yield (REGY) was maximum in case of rice-brinjal (239.12 q/ha) sequence. During rabi it was found that yield of component crops varied fairly according to cropping system. Whereas, during kharif rice yield was found highest $(51.32 \mathrm{q} / \mathrm{ha})$ under rice-groundnut sequence. Maximum monetary efficiency ( $1000 /$ ha/day) was obtained under rice-brinjal sequence followed by rice-sweet corn ( $875.1 /$ ha/day). Rice-brinjal cropping sequences registered highest land use efficiency $(76.71 \%)$ followed by rice-chilli $(75.34 \%)$ and rice-okra $(72.60 \%)$. Water use efficiency was lowest higher with rice-sweet corn $(30.94 \mathrm{~kg} / \mathrm{mm})$ followed by rice-brinjal $(22.11 \mathrm{~kg} / \mathrm{mm})$. The increase in available $\mathrm{N}, \mathrm{P}$ and $\mathrm{K}$ status after three year was observed with the inclusion of leguminous crop in the rotation.

\section{Introduction}

Rice is staple food crop and is widely cultivated in various types of soils in South Konkan Coastal Region of Maharashtra. The agro climatic conditions prevailing in the region are ideal to realize higher productivity of the crop. However, during recent years, owing to labour scarcity coupled with other socio-economic constraints like fragmented land holding, higher labour cost, lack of cooperative farming efforts, reluctant of youth to take up the noble profession of rice, the cropped area under rice is dwindling, posing a 
serious challenge to meet the food security of the region. This problem can partly be solved by changing from continuous rice-rice production to growing cropping systems like rice-sweet corn, rice-pulses, rice-oilseeds, rice-vegetables etc. in the region.

The traditional rice based cropping systems followed in the region are rice-cowpea, ricehorse gram under residual moisture situations and rice-groundnut, rice-vegetables under protective irrigation. There is an ample scope to improve both productivity and profitability in the system by identifying suitable crops through intensive management so as to enhance the returns of the rice grower and sustain the crop cultivation in the region. It has been reported that inclusion of sweet corn, pulses, oil seeds or vegetables in cropping system is more beneficial, as it increases the economics of the system and better utilization of residual moisture and fertilizers. Against this background, the present investigation is formulated to find out most profitable rice based cropping system for South Konkan Coastal Zone of Maharashtra.

\section{Materials and Methods}

Field experiment was conducted for three consecutive kharif-rabi seasons of 2012-13, 2013-14 and 2014-15 at Agricultural Research Station, Phondaghat, Dist. Sindhudurg (MS) India $\left(16-22^{0} 35^{\prime} \mathrm{N}, 73-41^{\circ} 18^{\prime} \mathrm{E}\right.$ and 145.10 $\mathrm{m}$ above mean sea level). The soil was clay loam having $5.8 \mathrm{pH}$, EC of $0.063 \mathrm{dSsqm}^{-1}$, 1.32 per cent organic carbon, $292 \mathrm{~kg} / \mathrm{ha}$ available nitrogen available, $5.6 \mathrm{~kg} / \mathrm{ha} \mathrm{P}_{2} \mathrm{O}_{5}$ and $98.4 \mathrm{~kg} / \mathrm{ha} \quad \mathrm{K}_{2} \mathrm{O}$. The total rainfalls received during three kharif seasons of experimental periods were $4287.5 \mathrm{~mm}$ (139 days), $3625.2 \mathrm{~mm}$ (112 days) and 2500.9 (105 days). The experiment was conducted with ten rice based cropping systems with an objective to find out most profitable rice based cropping system suitable for South Konkan Coastal
Zone. The experiment was laid out in randomized block design with three replications and ten treatments consist of nine crops raised during rabi after kharif rice. Treatment details are as Rice-Watermelon (Black Boy) ( $\left.\mathrm{T}_{1}\right)$, Rice-Chilli (Konkan Kirti) $\left(\mathrm{T}_{2}\right)$, Rice-Groundnut (TKG Bold) $\left(\mathrm{T}_{3}\right)$, RiceCabbage (Golden acre) $\left(\mathrm{T}_{4}\right)$, Rice-Sweet corn (Sugar 75) $\quad\left(\mathrm{T}_{5}\right)$, Rice-Okra (Niraml-Gopi NOH-1336) ( $\left.\mathrm{T}_{6}\right)$, Rice-Cowpea (Konkan Sadabahar) $\left(\mathrm{T}_{7}\right), \quad$ Rice-Brinjal (Suvarna Pratibha) $\left(\mathrm{T}_{8}\right)$ and Rice-Wal (Local) $\left(\mathrm{T}_{9}\right)$ along with Rice-fallow $\left(\mathrm{T}_{10}\right)$. After harvest of rainy season rice, field was ploughed twice, thoroughly pulverized and then rabi crops were sown during last week of December to $1^{\text {st }}$ week of January during all the three years of the study. Recommended standard cultivation package of practices were followed for the respective crops and harvested as per maturity. The seeds of chilli and cabbage were sown on raised beds in nursery for growing of sturdy seedlings during $1^{\text {st }}$ fortnight of December and 25 days old seedlings were transplanted. Sowing of remaining rabi season crops viz., watermelon, groundnut, sweet corn, okra, cowpea and wal were done manually during second fortnight of January in the main field. Seeds of legume crops were treated with crop specific Rhizobium and phospho-bacteria before sowing. The details of crop varieties, spacing maintained and fertilizers applied for different crops were given in Table 1. Whole of $\mathrm{P}$ and $\mathrm{K}$ and basal dose of $\mathrm{N}$ was applied in rows 2-3 $\mathrm{cm}$ below seeds before sowing/planting of crops whereas remaining dose of $\mathrm{N}$ was applied in split doses as per scientific recommendations. In rice, whole of $\mathrm{P}$ and $\mathrm{K}$ and basal dose of $\mathrm{N}$ was given before puddling and incorporated in soil. Urea was used as source of nitrogen, single super phosphate for phosphorus and muriate of potash for potassium.

In kharif season sowing of rice cv. Ratnagiri 4 was done during $1^{\text {st }}$ fortnight of June. In main 
field, to reduce the water losses through deep percolation and seepage, impervious soil layer was created in sub-surface by puddling which included 4-5 cross cultivations in $5 \mathrm{~cm}$ standing water in field by power tiller followed by leveling and bunding. Seedlings of 21 days of age old were transplanted manually in field during first week of July depending on onset of monsoon and crop was harvested in the last week of October. The rice crop was harvested at physiological maturity. Grain yield was recorded from the net plot area. The produce was properly sun dried up to 12 per cent moisture content. Days to maturity was recorded on the basis of physiological maturity.

In rice, entire water requirement of crop was met through rainfall. Rabi crops were grown entirely on supplemented irrigation from the wells available at farm. In rainy season, rainfall received during the crop period was satisfactory. Recommended intercultural practices and plant protection measures were followed as and when required for successful cultivation of crops. In rabi season, crops viz., watermelon, okra, and brinjal were harvested for fruit yield purpose, chilli and wal as a green pods, sweet corn as a cobs, groundnut as a pods and cowpea for grains. In rabi season several pickings were performed in almost all the crops as per maturity of fruits/pods except in groundnut, which was harvested at the end of crop period at physiological maturity.

For economic evaluation of different ricebased cropping sequences, mean data of three crop cycles were used. Economic yields of the component crops were converted to riceequivalent yield (REY), taking into account the prevailing market price. Whereas, biomass of remaining crops was removed from the plots after harvest of economic parts. The gross cost of cultivation of different crops grown was calculated on the basis of different operations performed and materials used for raising the crops. For treatment comparisons 'F test' was used, following the procedures of randomized block design (Cochran and Cox, 1957). Total field duration of a cropping system expressed in percentage of 365 days was taken as the land use efficiency (Tomar and Tiwari, 1990) of the system. Production efficiency was expressed as the ratio of system productivity in $\mathrm{kg} \mathrm{REY/ha} \mathrm{to} \mathrm{total} \mathrm{duration} \mathrm{of}$ the system in days (Patil et al., 1995). Water use efficiency (WUE) was computed by dividing system productivity with water requirement of the system and was expressed as $\mathrm{kg} \mathrm{REY} / \mathrm{mm}$ of water uses. Production efficiency and water use efficiency in economic term were calculated by taking net return instead of REY.

\section{Results and Discussion}

\section{System productivity}

Three years pooled data indicated that among different rice based crops cultivated during rabi after kharif rice, brinjal recorded higher fruit yield followed by watermelon, cabbage and sweet corn. Whereas, rice equivalent yield of rabi crops as well as rice equivalent yield of system were higher with brinjal followed by sweet corn, okra and chilli. The system productivity in terms of rice equivalent grain yield (REGY) was maximum in case of ricebrinjal (239.12 q/ha) sequence (Table 2). It can be attributed mainly to brinjal productivity (210.69 q/ha) besides fetching average prices in the market ( $14.00 / \mathrm{kg}$ ). The next in the order was rice-sweet corn cropping sequence. Here, sweet corn crop contributed more (76.56\%) to enhance the equivalent yield due to its higher marketable yield (Cobs 135.00 q/ha and Straw 194.42 q/ha). The crops like brinjal, sweet corn and groundnut were governed the REGY of the systems. Mishra et al., (2007) also reported higher productivity and profitability through inclusion of vegetables and pulses in rice-based cropping 
system. Results of higher yields by rice-maize cropping system have been also reported by Rao et al., (2014) and Kumar et al., (2005). Lowest REGY (43.83 q/ha) was recorded under rice-fallow $(43.83 \mathrm{q} / \mathrm{ha})$ followed by rice-wal (95.34 q/ha) system and rice-cowpea $(107.21 \mathrm{q} / \mathrm{ha})$, which was mainly due to low yield levels of wal and cowpea crops, which were at par with each other.

During rabi it was found that yield of component crops varied fairly according to cropping system. Whereas, during kharif rice yield was found highest $(51.32 \mathrm{q} / \mathrm{ha})$ under rice-groundnut sequence, which was at par with almost all crop sequences (Table 2). Results of incorporation of legume crops in rice-based cropping system increased the productivity of rice has been also reported by Hegde (1992) and Jat et al., (2012). Minimum rice yield was recorded under rice-brinjal $(43.78 \mathrm{q} / \mathrm{ha})$. It might be due to nutrient exhaustive nature of brinjal crop which adversely affects the growth and development of succeeding rice in the rotation.

\section{Economics}

Data on economics of rice based cropping systems revealed that, rice-brinjal system recorded the highest cost of cultivation, followed by rice-sweet corn and rice-chilli, while rice-fallow recorded less cost of cultivation followed by rice-wal and ricecowpea systems. Inclusion of vegetables like brinjal and sweet corn, chilli in these cropping systems besides, increasing the system productivity, fetched higher market price thereby, increasing the net returns. Kumar et al., (2008) also reported that inclusion of vegetative crops in rice based cropping system improved the net returns. Gross returns were higher in rice-brinjal system followed by ricesweet corn and rice-okra systems. The higher gross returns were owing to higher yields of brinjal and rice in the sequences. Rice-Sweet corn crop sequence secured significantly higher net returns of ' $135894.00 /$ ha followed by Rice-Brinjal (' 130618.00/ha) crop sequence. However, rice- watermelon, ricechilli and rice- groundnut remained at par in terms of net returns. The returns per rupee invested were highest for rice-sweet corn (1.74), rice-brinjal (1.56), rice-groundnut (1.42) and rice-watermelon (1.35). This was due to high gross returns of these systems. Growing of vegetable crops during rabi in areas with assured irrigation facilities is economically remunerative as supply of vegetables from rainfed areas is drastically reduced during $r a b i$ and vegetable prices soar up (Jat et al., 2012).

Table.1 Details of the crops, varieties, spacing and fertilizers used in cropping system

\begin{tabular}{|c|c|c|c|c|c|}
\hline $\begin{array}{l}\text { Sr. } \\
\text { No. }\end{array}$ & Season & Crop & Variety & $\begin{array}{c}\text { Spacing } \\
\text { (cm) }\end{array}$ & $\begin{array}{c}\text { Fertilizers } \\
\text { N: P: K (kg/ha) }\end{array}$ \\
\hline 1 & Kharif & Rice (Oryza sativa L.) & Ratnagiri 4 & $20 \times 15$ & 100: $50: 50$ \\
\hline 2 & Rabi & Watermelon (Citrullus lanatus) & Black Boy & $200 \times 50$ & 150: $50: 50$ \\
\hline 3 & Rabi & Chilli (Capsicum аппиит) & Konkan Kirti & $60 \times 45$ & 150: $50: 50$ \\
\hline 4 & Rabi & Groundnut (Arachis hypogaea L.) & TKG Bold & $30 \times 15$ & 25: $50: 00$ \\
\hline 5 & Rabi & Cabbage (Brassica oleracea var. capitata) & Golden acre & $45 \times 45$ & 120: $60: 60$ \\
\hline 6 & Rabi & Sweet Corn (Zea mays var. saccharata) & Sugar 75 & $60 \times 20$ & 200: $60: 60$ \\
\hline 7 & Rabi & Okra (Abelmoschus esculentus) & Nirmal-Gopi & $45 \times 15$ & 100: $50: 50$ \\
\hline 8 & Rabi & Cowpea (Vigna sinensis.) & Konkan Sadabahar & $30 \times 15$ & 25: $50: 00$ \\
\hline 9 & Rabi & Brinjal (Solanum melongena) & Swarna Pratibha & $60 \times 60$ & 150: $50: 50$ \\
\hline 10 & Rabi & Wal (Dolichos lablab L) & Local & $30 \times 15$ & 25: 50: 00 \\
\hline 11 & Rabi & Fallow & -- & -- & -- \\
\hline
\end{tabular}


Table.2 Mean yield and gross monetary returns from various crop sequences

\begin{tabular}{|c|c|c|c|c|c|c|c|c|c|c|}
\hline \multirow[t]{2}{*}{ Treatment } & \multicolumn{2}{|c|}{$\begin{array}{l}\text { Mean grain/fruit } \\
\text { yield (q/ha) }\end{array}$} & \multicolumn{2}{|c|}{$\begin{array}{l}\text { Straw yield } \\
\text { (q/ha) }\end{array}$} & \multirow{2}{*}{$\begin{array}{l}\text { REGY } \\
\text { (q/ha) } \\
\text { of Rabi }\end{array}$} & \multirow{2}{*}{$\begin{array}{c}\text { Total } \\
\text { REGY } \\
(\mathbf{q} / \mathbf{h a}) \\
(\mathbf{K}+\mathbf{R})\end{array}$} & \multirow{2}{*}{$\begin{array}{l}\text { Total } \\
\text { gross } \\
\text { returns } \\
(\mathcal{h} / \mathbf{h a}) \\
(\mathbf{K}+\mathbf{R})\end{array}$} & \multirow{2}{*}{$\begin{array}{c}\text { Total } \\
\text { cost of } \\
\text { cultivation } \\
(/ / h a) \\
(\mathbf{K}+\mathbf{R})\end{array}$} & \multirow{2}{*}{$\begin{array}{c}\text { Net } \\
\text { returns } \\
(\text { ' } / \mathbf{h a}) \\
(\mathbf{K}+\mathbf{R})\end{array}$} & \multirow[t]{2}{*}{$\begin{array}{l}\text { B: } \mathbf{C} \\
\text { ratio }\end{array}$} \\
\hline & $\begin{array}{l}\text { Kharif } \\
\text { (K) }\end{array}$ & $\begin{array}{c}\text { Rabi } \\
(\mathbf{R})\end{array}$ & $\begin{array}{l}\text { Kharif } \\
\text { (K) }\end{array}$ & $\begin{array}{c}R a b i \\
(\mathbf{R})\end{array}$ & & & & & & \\
\hline $\begin{array}{l}\mathbf{T}_{1}: \text { Rice - } \\
\text { Watermelon* }\end{array}$ & 48.32 & 189.74 & 56.25 & -- & 113.09 & 161.42 & 247971 & 184309 & 63663 & 1.35 \\
\hline $\mathrm{T}_{2}$ : Rice - Chilli *** & 49.28 & 79.08 & 57.71 & -- & 125.69 & 174.97 & 268578 & 211613 & 56965 & 1.27 \\
\hline $\begin{array}{l}T_{3}: \text { Rice - } \\
\text { Groundnut }\end{array}$ & 51.32 & 27.85 & 58.51 & 32.10 & 87.26 & 138.58 & 213564 & 150157 & 63408 & 1.42 \\
\hline $\mathrm{T}_{4}$ : Rice - Cabbage & 47.93 & 167.91 & 58.93 & -- & 111.20 & 159.13 & 244957 & 202326 & 42631 & 1.21 \\
\hline $\begin{array}{l}\mathbf{T}_{5} \text { : Rice - Sweet } \\
\text { Corn } * * * *\end{array}$ & 48.93 & 135.00 & 56.05 & 194.42 & 159.85 & 208.78 & 319414 & 183520 & 135894 & 1.74 \\
\hline $\mathrm{T}_{6}$ : Rice - Okra* & 44.15 & 98.58 & 54.03 & -- & 156.68 & 200.82 & 307509 & 232670 & 74839 & 1.32 \\
\hline $\mathrm{T}_{7}$ : Rice - Cowpea & 48.30 & 14.17 & 52.38 & 19.75 & 58.91 & 107.21 & 165543 & 129273 & 36270 & 1.28 \\
\hline $\mathrm{T}_{8}$ : Rice - Brinjal* & 43.78 & 210.69 & 53.49 & -- & 195.34 & 239.12 & 365294 & 234676 & 130618 & 1.56 \\
\hline$T_{9}$ : Rice - Wal & 45.37 & 10.43 & 53.68 & 12.24 & 49.97 & 95.34 & 148067 & 116855 & 31212 & 1.27 \\
\hline $\mathrm{T}_{10}$ : Rice - Fallow & 43.83 & -- & 55.66 & -- & -- & 43.83 & 70719 & 65449 & 5269 & 1.08 \\
\hline $\mathrm{SE}(\mathrm{m}) \pm$ & 2.15 & 5.11 & 2.32 & -- & 3.88 & 3.95 & -- & -- & 3002.93 & 0.02 \\
\hline CD at $5 \%$ & 6.07 & 14.47 & 6.56 & -- & 11.63 & 11.73 & -- & -- & 8922.15 & 0.07 \\
\hline
\end{tabular}

* Fruit yield, **Green pod yield and *** Cob yield

Selling rates $\left(\mathrm{q}^{-1}\right)$ of main products and byproducts during final year of experiment

\begin{tabular}{|l|c|c|c|c|c|c|c|c|c|c|}
\hline Crop & $\begin{array}{c}\text { Watermelon } \\
\text { (fruits) }\end{array}$ & $\begin{array}{c}\text { Chilli } \\
\text { (green) }\end{array}$ & $\begin{array}{c}\text { Groundnut } \\
\text { (dry pods) }\end{array}$ & $\begin{array}{c}\text { Cabbage } \\
\text { (heads) }\end{array}$ & $\begin{array}{c}\text { Sweet corn } \\
\text { (corns) }\end{array}$ & $\begin{array}{c}\text { Okra } \\
\text { (fruits) }\end{array}$ & $\begin{array}{c}\text { Cowpea } \\
\text { (grains) }\end{array}$ & $\begin{array}{c}\text { Brinjal } \\
\text { (fruits) }\end{array}$ & $\begin{array}{c}\text { Wal } \\
\text { (grains) }\end{array}$ & $\begin{array}{c}\text { Rice } \\
\text { (grains) }\end{array}$ \\
\hline Main Product & 900 & 2400 & 4500 & 1000 & 1500 & 2400 & 6000 & 1400 & 7000 & 1510 \\
\hline Straw & -- & -- & 200 & -- & 200 & -- & 200 & -- & 200 \\
\hline
\end{tabular}


Table.3 Crop durations, irrigations applied, water use efficiency, productivity and gross monetary efficiency of different rice based cropping system

\begin{tabular}{|c|c|c|c|c|c|c|c|c|c|}
\hline \multicolumn{2}{|c|}{$\begin{array}{c}\text { Crop sequence } \\
\text { (Duration in days) }\end{array}$} & \multirow{2}{*}{$\begin{array}{l}\text { Duration } \\
\text { of the } \\
\text { system } \\
\text { (days) }\end{array}$} & \multirow{2}{*}{$\begin{array}{l}\text { Land use } \\
\text { efficiency } \\
(\%)\end{array}$} & \multirow[t]{2}{*}{$\begin{array}{l}\text { No. of } \\
\text { irrigations }\end{array}$} & \multirow{2}{*}{$\begin{array}{l}\text { Quantity } \\
\text { of water } \\
\text { applied to } \\
\text { Rabi crops } \\
\text { (mm) }\end{array}$} & \multirow{2}{*}{$\begin{array}{l}\text { FWUE of } \\
\text { Rabi crops } \\
\text { on the basis } \\
\text { of yield } \\
\text { (kg/mm) }\end{array}$} & \multirow{2}{*}{$\begin{array}{l}\text { FWUE of } \\
\text { Rabi crops } \\
\text { based } \\
\text { on REY } \\
\text { (kg/mm) }\end{array}$} & \multirow{2}{*}{$\begin{array}{c}\text { Production } \\
\text { efficiency*** } \\
\text { of the } \\
\text { system } \\
\text { (kg/ha/day) }\end{array}$} & \multirow{2}{*}{$\begin{array}{l}\text { Monetary } \\
\text { efficiency } \\
\text { of the } \\
\text { system } \\
\text { (Rs/ha/day) }\end{array}$} \\
\hline Kharif & Rabi* & & & & & & & & \\
\hline $\begin{array}{l}\text { Rice } \\
\text { (130) }\end{array}$ & $\begin{array}{l}\text { Watermelon } \\
(100)\end{array}$ & 230 & 63.01 & 14.0 & 700.0 & 27.11 & 16.16 & 44.22 & 679.4 \\
\hline $\begin{array}{l}\text { Rice } \\
(130) \\
\end{array}$ & $\begin{array}{l}\text { Chilli } \\
\text { (145) }\end{array}$ & 275 & 75.34 & 17.0 & 850.0 & 9.30 & 14.79 & 47.94 & 735.8 \\
\hline $\begin{array}{l}\text { Rice } \\
\text { (130) }\end{array}$ & $\begin{array}{l}\text { Groundnut } \\
(125)\end{array}$ & 255 & 69.86 & 13.7 & 683.3 & 4.08 & 12.77 & 37.97 & 585.1 \\
\hline $\begin{array}{l}\text { Rice } \\
(130) \\
\end{array}$ & $\begin{array}{l}\text { Cabbage } \\
(115)\end{array}$ & 245 & 67.12 & 13.3 & 666.7 & 25.19 & 16.68 & 43.60 & 671.1 \\
\hline $\begin{array}{l}\text { Rice } \\
(130) \\
\end{array}$ & $\begin{array}{l}\text { Sweet Corn } \\
(90)\end{array}$ & 220 & 60.27 & 10.3 & 516.7 & 26.13 & 30.94 & 57.20 & 875.1 \\
\hline $\begin{array}{l}\text { Rice } \\
\text { (130) }\end{array}$ & $\begin{array}{l}\text { Okra } \\
(135)\end{array}$ & 265 & 72.60 & 16.0 & 800.0 & 12.32 & 19.58 & 55.02 & 842.5 \\
\hline $\begin{array}{l}\text { Rice } \\
(130) \\
\end{array}$ & $\begin{array}{l}\text { Cowpea } \\
(70)\end{array}$ & 200 & 54.79 & 8.0 & 400.0 & 3.54 & 14.73 & 29.37 & 453.5 \\
\hline $\begin{array}{l}\text { Rice } \\
(\mathbf{1 3 0}) \\
\end{array}$ & $\begin{array}{l}\text { Brinjal } \\
(150)\end{array}$ & 280 & 76.71 & 17.7 & 883.3 & 23.85 & 22.11 & 65.51 & 1000.8 \\
\hline $\begin{array}{l}\text { Rice } \\
(\mathbf{1 3 0}) \\
\end{array}$ & $\begin{array}{l}\text { Wal } \\
(100)\end{array}$ & 230 & 63.01 & 10.7 & 533.3 & 1.96 & 9.37 & 26.12 & 405.7 \\
\hline $\begin{array}{l}\text { Rice } \\
\text { (130) }\end{array}$ & Fallow & 130 & 35.62 & -- & -- & -- & -- & 12.01 & 193.7 \\
\hline $\begin{array}{l}* \text { Irriga } \\
* * \text { Base } \\
\text { FWUE } \\
\text { GME }= \\
\text { REY = }\end{array}$ & $\begin{array}{l}\text { Is were given to } I \\
\text { n } 365 \text { days of the } \\
\text { ield water use ef } \\
\text { oss monetary eff } \\
\text { e equivalent yiel }\end{array}$ & $\begin{array}{l}\text { abi crops only } \\
\text { year } \\
\text { iciency } \\
\text { ciency }\end{array}$ & & & & & & & \\
\hline
\end{tabular}




\section{Resource use efficiency}

Rice- brinjal cropping sequences registered highest land use efficiency $(76.71 \%)$ followed by rice- chilli $(75.34 \%)$ and rice- okra (72.60\%). It attributed mainly due to brinjal, chilli and okra crops which occupied the field for about 150, 145 and 135 days, respectively. The land use efficiency (LUE) was lowest in rice- fallow $(35.62 \%)$ followed by ricecowpea $(54.79 \%)$ crop sequences, indicating that it has scope to include one more short duration crop in rice- cowpea system. Ricebrinjal sequence registered the highest production efficiency $(65.51 \mathrm{~kg} / \mathrm{ha} /$ day $)$ followed by rice-sweet corn $(57.20$ $\mathrm{kg} / \mathrm{ha} / \mathrm{day})$. It was closely followed by riceokra sequence, with $55.02 \mathrm{~kg} / \mathrm{ha} /$ day of production efficiency. Lowest production efficiency was found with rice- fallow (12.01 $\mathrm{kg} / \mathrm{ha} / \mathrm{day})$ followed by rice-wal (26.12 $\mathrm{kg} / \mathrm{ha} / \mathrm{day}$ ) sequences. Among the different crops during rabi water use efficiency was lowest in rice- wal $(9.37 \mathrm{~kg} / \mathrm{mm})$ followed by rice- groundnut $(12.77 \mathrm{~kg} / \mathrm{mm})$, rice- cowpea $(14.73 \mathrm{~kg} / \mathrm{mm})$ and rice- chilli $(14.79 \mathrm{~kg} / \mathrm{mm})$. While, it was higher with rice- sweet corn $(30.94 \mathrm{~kg} / \mathrm{mm})$ followed by rice- brinjal $(22.11 \mathrm{~kg} / \mathrm{mm})$ and rice- okra $(19.58 \mathrm{~kg} / \mathrm{mm})$ based on REY because of higher production with less water use (Table 3). Maximum monetary efficiency (c 1000/ha/day) was obtained under rice- brinjal sequence followed by rice- sweet corn ( $875.1 /$ ha/day).

The increase in available $\mathrm{N}, \mathrm{P}$ and $\mathrm{K}$ status after three year was observed with the inclusion of leguminous crop in the rotation. Among the cropping systems tested ricegroundnut, rice- cowpea and rice- wal significantly improved the soil available nitrogen, phosphorus and potassium status. The preceding crop species can have a beneficial or detrimental effect on the performance of the succeeding crop. The well-known beneficial effects of preceding legume crop on cereal are also found in multiple cropping systems, but the magnitude of the effects varies with management practices and the legume species used (Porpavai et al., 2011). Maximum apparent nutrient productivity was recorded in RiceBrinjal (53.14 kg/ha) followed by RiceGroundnut (50.39 kg/ha) and Rice- Okra $(50.21 \mathrm{~kg} / \mathrm{ha})$ cropping systems.

Based on findings of this experiments it can be concluded that under the conditions of South Konkan Coastal Zone of Maharashtra, rice- sweet corn was found most profitable cropping system followed by rice- brinjal on the basis of net returns and $\mathrm{B}$ : $\mathrm{C}$ ratio as it was more productive, sustainable, resourceuse efficient and remunerative.

\section{References}

Cochran, W.G. and G.M. Cox. 1957. Experimental Designs. Wiley, NY, USA.

Hegde, D.M. 1992. Cropping System Research- Highlights. Project Directorate for Cropping System Research, Modipuram, Meerut, Utter Pradesh. pp. 40.

Jat, R.A., R.A. Dungrani, M.K. Arvadia and K.L. Sahrawat. 2012. Diversification of rice (Oryza sativa L.) based cropping systems for higher productivity, resource-use efficiency and economic returns in South Gujarat of India. Archives of Agronomy and Soil Science. 58(6): 561-72.

Kumar A., H.P. Tripathi, R.A. Yadav and S.R. Yadav, 2008. Diversification of rice (Oryza sativa L.)- wheat (Triticum aestivum) cropping system for sustainable production in eastern Uttar Pradesh. Indian Journal of Agronomy 53(1): 18-21.

Kumar, K.A., N.V. Reddy and K.S. Rao. 2005. Profitable and energy efficient 
rice based cropping systems in northern Telangana of Andhra Pradesh. Indian Journal of Agronomy 50(1): 6-9.

Patil, E.N., S. Jowale and M.S. Mahayan. 1995. Production potential, economics and fertility status of soil as influenced by wheat - based cropping system. Indian Journal of Agronomy 40(40): $544-48$.

Porpavai, S., P. Devasenapathy, K. Siddeswaran and T. Jayaraj. 2011. Impact of various rice based cropping systems on soil fertility. Journal of Cereals and Oilseed 2(3): 43-46.

Rao, U.A., T.V. Sridhar, D.A. Lakshmi and K.S. Raju. 2014. Identification of viable rice based cropping systems for double cropped delta areas of Andhra Pradesh. International Journal of Science and Nature 5(3): 512-514.

Tomar, S.S. and A.S. Tiwari. 1990. Production potential and economics of different cropping sequences. Indian Journal of Agronomy 35(1, 2): 30-35.

\section{How to cite this article:}

Chavan, A.P., N.G. Sonone, M.S. Jadhav and Sagvekar, V.V. 2018. Identification of Profitable Rice Based Cropping System for South Konkan Coastal Zone. Int.J.Curr.Microbiol.App.Sci. 7(10): 289-296. doi: https://doi.org/10.20546/ijcmas.2018.710.030 